\title{
Amenorrhoea, Galactorrhoea, and Primary Hypothyroidism with High Circulating Levels of Prolactin
}

\author{
C. R. W. EDWARDS, ISABEL A. FORSYTH, G. M. BESSER
}

British Medical fournal, 1971, 3, 462-464

\section{Summary}

A 22-year-old woman with primary hypothyroidism developed amenorrhoea and galactorrhoea during oral contraceptive therapy. Investigation showed high levels of circulating prolactin which rose in response to insulininduced hypoglycaemia and were suppressed by an oral glucose load. After treatment with thyroxine normal periods returned, the galactorrhoea improved, and the prolactin levels fell to undetectable levels. The results of the prolactin and human growth hormone assays confirm that it is possible to distinguish between human growth hormone and human prolactin.

\section{Introduction}

Since the first description by Hennes et al. (1960) of the syndrome of amenorrhoea, galactorrhoea, and primary hypothyroidism 12 further cases have been reported (Dowling et al., 1961; Arenas et al., 1962; Bercovici and Ehrenfield, 1963; Canfield and Bates, 1965; Ross and Nusynowitz, 1968; Bayliss and Van't Hoff, 1969; Kinch et al., 1969; Futterweit and Goodsell, 1970). With one exception the galactorrhoea and amenorrhoea in these cases developed after delivery and disappeared with thyroid replacement therapy. Prolactin was not measured in these patients, but it was suggested that the galactorrhoea was secondary to high circulating levels of this pituitary polypeptide. In the present case the galactorrhoea developed during oral contraceptive therapy and was associated with high levels of circulating prolactin as measured by bioassay (Forsyth, 1969). This patient has been briefly referred to in an earlier paper (Case 11, Forsyth et al., 1971).

\section{Case Report}

A 22-year-old woman had a normal pregnancy in 1966 followed by lactation for two weeks which was suppressed by oestrogen therapy. From January 1968 to July 1969 she was on oral contraceptives with normal withdrawal bleeding. In July 1969 six days before stopping Ortho-Novin (norethisterone $1 \mathrm{mg}$, mestranol $0.08 \mathrm{mg}$ ) she developed galactorrhoea. This was followed by an episode of menorrhagia in August and then amenorrhoea. In February 1970 she felt generally unwell and had cold intolerance, dry skin, and poor memory. She was found to have a normochromic, normocytic anaemia and was admitted to hospital in April 1970 for further investigation of this and her persistent galactorrhoea and amenorrhoea. Physical examination suggested a diagnosis of hypothyroidism, and the thyroid gland was just palpable. Both breasts were active and milk was easily expressed.

\footnotetext{
Medical Professorial Unit, St. Bartholomew's Hospital, London EC1A 7BE

C. R. W. EDWARDS, M.B., M.R.C.P., Lecturer in Medicine

G. M. BESSER, M.D., M.R.C.P., Senior Lecturer in Endocrinology

National Institute for Research in Dairying, Shinfield, Reading, Berks

ISABEL A. FORSYTH, M.A., D.PHIL., Senior Scientific Officer
}

INVESTIGATIONS

Thyroid Function Tests.-Protein-bound iodine $2 \cdot 2 \mu \mathrm{g} / 100 \mathrm{ml}$; T-3 resin uptake $25.7 \%$; serum total thyroxine $2.3 \mu \mathrm{g} / 100 \mathrm{ml}$; serum cholesterol $400 \mathrm{mg} / 100 \mathrm{ml}$; ${ }^{131} \mathrm{I}$ uptake $6 \%$ at 24 hours and $5 \% 24$ hours after $10 \mathrm{IU}$ thyroid stimulating hormone (Armour, TSH) intramuscularly daily for three days. Serum immunoreactive TSH $103 \mu \mathrm{U} / \mathrm{ml}$ (normal less than $5 \mu \mathrm{U} / \mathrm{ml}$ ) (Fig. 1).

Antibody Studies. - Thyroglobulin tanned cell agglutination titre 1:640; cytoplasmic antibodies positive ++ ; gastric parietal cell antibodies positive +++ ; intrinsic factor antibodies negative (Dr. Deborah Doniach). Adrenal antibodies negative; ovarian and kidney mitochondrial antibodies negative (Dr. W. J. Irvine). Urinary immunoreactive luteinizing hormone (LH) (Searle Scientific Services) 19.4 and 5.2 IU/24 hr (normal in follicular phase: 5-45 IU 2nd IRP, HMG/24 hr), total urinary oestrogen $2.7 \mu \mathrm{g} / 24 \mathrm{hr}$. Plasma fluorogenic corticosteroids 9 a.m. $16 \mu \mathrm{g} / 100 \mathrm{ml}$, midnight $8 \mu \mathrm{g} / 100 \mathrm{ml}$

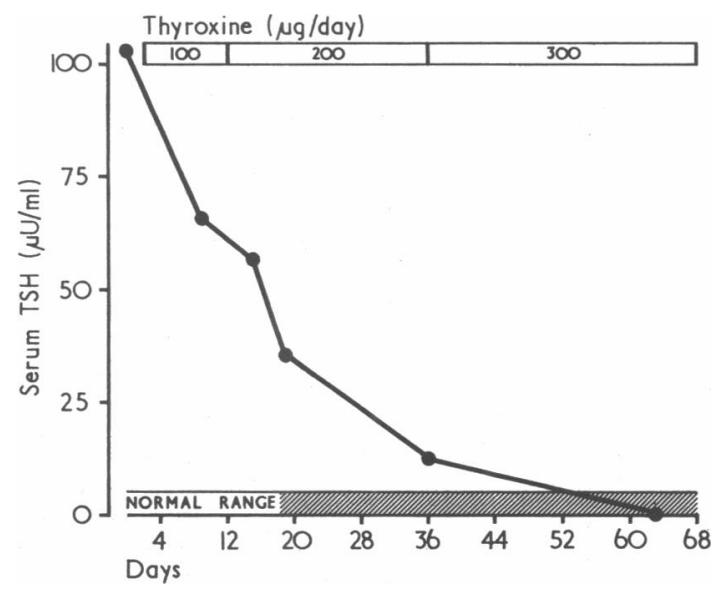

FIG. 1-Serum immunoreactive T.S.H. levels before and during treatment with thyroxine.

Insulin tolerance tests were performed before treatment and after 6 and 12 months on thyroxine. Measurements of blood sugar, plasma immunoreactive growth hormone (GH), plasma fluorogenic corticosteroids, and bioactive prolactin levels were made, and the results are shown in Figs. 2 and 3.

Glucose tolerance tests ( $50 \mathrm{~g}$ by mouth) were performed before and after treatment with thyroxine, and blood sugar, plasma prolactin, and growth hormone levels were measured. There was no significant difference between the fasting blood sugars, the peak responses, and the two-hour blood sugar levels before and after taking thyroxine for 6 and 12 months. The mean fasting blood sugar was $74 \mathrm{mg} / 100 \mathrm{ml}$, the peak $116 \mathrm{mg} / 100 \mathrm{ml}$, and the two-hour level $100 \mathrm{mg} / 100 \mathrm{ml}$. The prolactin and growth hormone results are shown in Fig. 4. Before treatment the prolactin levels were very high $(2,000 \mathrm{ng} / \mathrm{ml})$, rose during the insulin tolerance test, and suppressed during the glucose tolerance test. At six months the prolactin levels were lower $(100-600 \mathrm{ng} / \mathrm{ml})$ and were undetectable at 12 months.

Schilling Test.-Part I : $8.1 \%$ of the dose of $0.5 \mu \mathrm{C}{ }^{58} \mathrm{Co}$-labelled vitamin $B_{12}$ excreted in urine in 24 hours (normal excretion $>10 \%$ of dose in 24 hours). Part II (with intrinsic factor): $10.9 \%$ of dose excreted. After six months' treatment with thyroxine-Part I $12.5 \%$; Part II $18.8 \%$. Skull $x$-ray films showed no evidence of a pituitary tumour. 


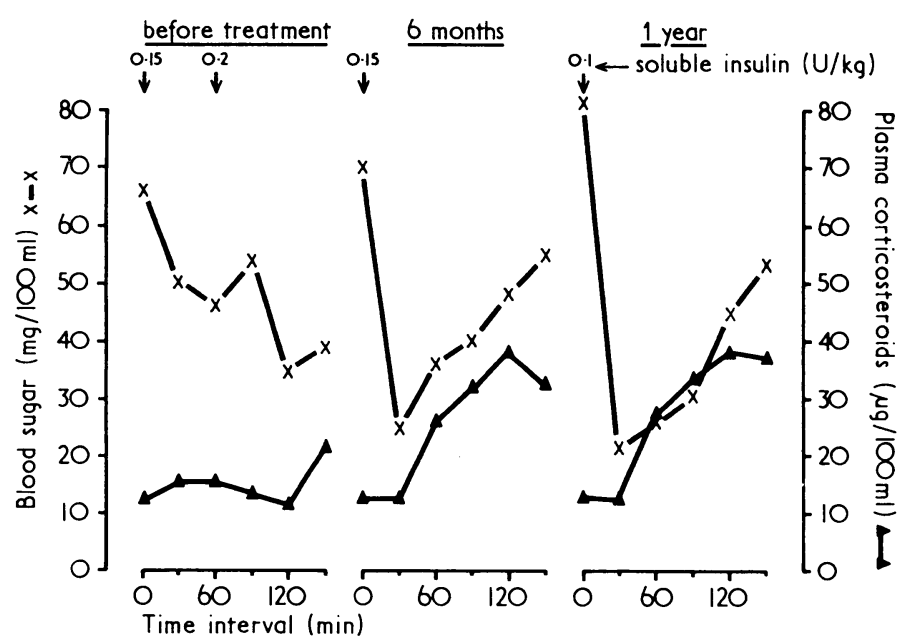

FIG. 2-Insulin tolerance tests before and at 6 and 12 months after starting thyroxine: blood sugar and plasma fluorogenic corticosteroid responses.

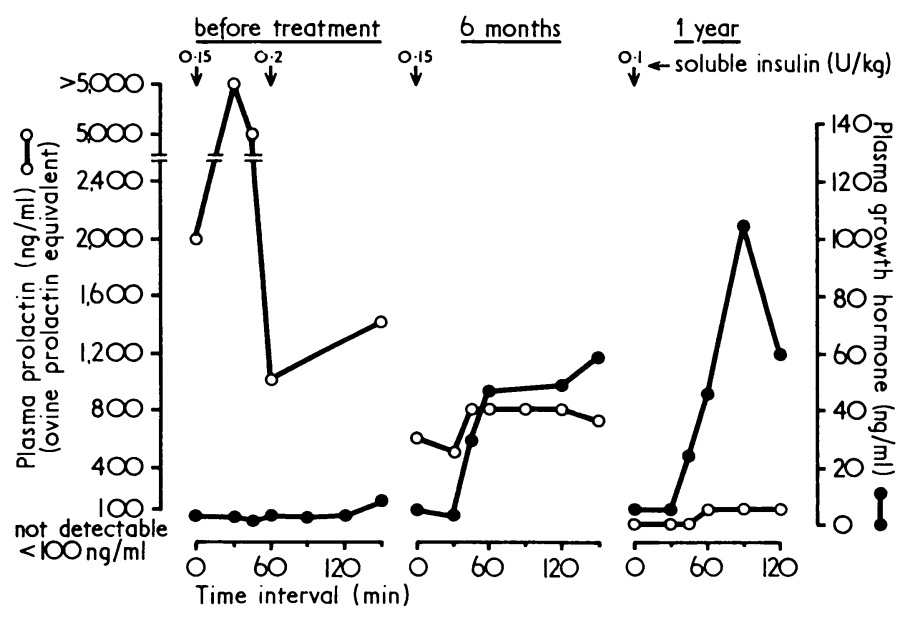

FIG. 3-Insulin tolerance tests before and at 6 and 12 months after starting thyroxine: plasma growth hormone and prolactin responses.

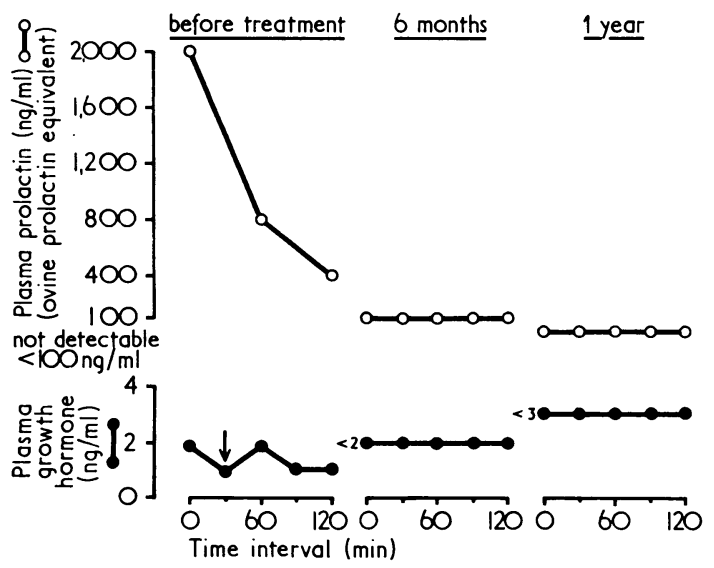

FIG. 4-Glucose tolerance tests before and at 6 and 12 months after starting thyroxine: plasma growth hormone and prolactin responses.

Prolactin bioassays were performed as previously described (Forsyth, 1969). Plasma samples were added at a concentration of $10 \%$ to explanted lobuloalveolar mammary tissue from rabbits on the 11th day of pseudopregnancy. The tissue culture medium (Medium 199) contained insulin $(5 \mu \mathrm{g} / \mathrm{ml})$ and corticosterone (1 $\mu \mathrm{g} / \mathrm{ml}$ ). Sheep prolactin (NIH-P-S6, $25 \mathrm{IU} / \mathrm{mg}$ ) was used as standard. The cultures were incubated for five days. The secretory responses were assessed on serial sections of the explants with an arbitrary grading system. The assay is equally sensitive to both growth hormone and prolactin. The minimum detectable amount of each is $10 \mathrm{ng}$, equivalent to $100 \mathrm{ng} / \mathrm{ml}$ in plasma added to the culture medium at a concentration of $10 \%$.

Growth Hormone Radioimmunoassay.-The growth hormone preparation used as standard and for iodination was M.R.C. "Human Growth Hormone for radioiodination-69/46." Antibodies were produced in rabbits with Imperial Cancer Research Fund HGH batch 6 for immunization. The antiserum used in the:e assays was from rabbit 2 , bled 13 October 1967 . The second antibody used for the separation of bound and free hormone was antirabbit globulin MR66 (Wellcome Reagents Ltd.).

Control Plasmas.-Plasmas from 1 male and 25 female subjects (age range 5 to 81 years) without evidence of endocrine disease showed no prolactin activity in the bioassay. Three out of eight control patients with primary hypothyroidism but no galactorrhoea had raised prolactin levels in the plasma (concentrations of between 500 and $1,000 \mathrm{ng} / \mathrm{ml}$ ).

TREATMENT AND PROGRESS

The clinical diagnosis of hypothyroidism was confirmed biochemically. The high circulating TSH levels, the positive thyroid antibody results, and the absence of an increased uptake of ${ }^{131}$ I after injection of TSH suggested that this was primary hypothyroidism. Treatment with thyroxine $100 \mu \mathrm{g}$ daily was started and the dose gradually increased to $300 \mu \mathrm{g}$ daily (Fig. 1). Fourteen weeks after starting thyroxine menstruation returned and has been regular since then. The serum TSH levels returned to the normal range after two months. After six months' therapy the galactorrhoea was greatly decreased, and at 12 months only a few drops of milk could be expressed.

\section{Discussion}

In the previous 13 cases of the syndrome of amenorrhoea, galactorrhoea, and primary hypothyrodism that have been described the galactorrhoea has been presumed to be due to high circulating levels of prolactin, but these have not been measured. This seems to be the first case in which high circulating levels of prolactin have been found. With the use of this in-vitro bioassay normal plasma contains no detectable prolactin-that is, less than $100 \mathrm{ng} / \mathrm{ml}$.

The secretion of prolactin in this patient did not seem to be autonomous in that the plasma prolactin rose in response to insulin-induced hypoglycaemia (Fig. 3) and was partially suppressed by an oral glucose load (Fig. 4). This is in contrast with patients with galactorrhoea associated with pituitary tumours in whom we have found no suppression of plasma prolactin during a glucose tolerance test (Forsyth et al., 1971).

Growth hormone produces an equivalent lactogenic response in the prolactin bioassay, but the highest levels of prolactin were found at a time when the growth hormone levels were $2 \mathrm{ng} / \mathrm{ml}$ or less. During the initial insulin tolerance test the growth hormone response to hypoglycaemia was appreciably impaired. The basal prolactin level was 1,000 times greater than the basal growth hormone level and during hypoglycaemia rose to greater than $5,000 \mathrm{ng} / \mathrm{ml}$ at a time when the growth hormone level was unchanged at $2 \mathrm{ng} / \mathrm{ml}$. These results suggest that it is possible to distinguish between human growth hormone and human prolactin. Such a distinction has been denied (Bewley and $\mathrm{Li}, 1970)$. Other evidence, such as study of a pituitary tumour removed from a patient with galactorrhoea and amenorrhoea (Peake et al., 1969), fetal pituitaries in tissue culture 
(Pasteels, 1969; Friesen et al., 1970), as well as measurements of plasma growth hormone and prolactin levels in galactorrhoeic patients (Frantz and Kleinberg 1970; Forsyth et al., 1971), suggests the separate existence of prolactin in man.

As has been described in other cases of hypothyroidism (Havard et al., 1970) there was pronounced insulin resistance in this patient before thyroxine therapy. A second dose of insulin was required during the initial insulin tolerance test to produce adequate hypoglycaemia - that is, sweating and a blood sugar of less than $40 \mathrm{mg} / 100 \mathrm{ml}$. Despite this the growth hormone response was impaired. In contrast, the insulin sensitivity after six months and one year on thyroxine was normal, as was the growth hormone response. The lactogenic activity detected at one year during the insulin tolerance test can be accounted for entirely by the concentrations of growth hormone rather than prolactin.

Bayliss and Van't Hoff (1969) suggested that the postpartum state is a prerequisite for the development of this condition, and thought that the comparative rarity of pregnancy in myxoedema explains why this condition is seldom seen. Of the cases described this is the only one that developed during treatment with an oestrogen-progestogen combination rather than postpartum. Several euthyroid patients have now been reported in whom galactorrhoea has developed in association with oral contraceptive therapy (Shearman and Turtle, 1970). In the above case it seems unlikely that the galactorrhoea was due to the contraceptive therapy alone since it persisted unabated until thyroid replacement was begun. The finding that plasma prolactin levels are raised in some patients with hypothyroidism but without galactorrhoea suggests that some type of oestrogen-progestogen priming of the breast facilitates the development of this syndrome.
We are indebted to Dr. Deborah Doniach and Dr. W. J. Irvine for the antibody studies, to Professor R. Hall for the TSH assays, to Sir Ronald Bodley Scott for referring this case, to Miss Lynn Francis for technical assistance with prolactin assays, and to Ciba Labo:atories and the Governors of St. Bartholomew's Hospital for financial support.

\section{References}

Arenas, A. M., Duran Martinez, L., Charco Entrena, F., and Higuera Rojas, J. (1962). Revista Clinica Española, 86, 229.

Bayliss, P. F. C., and Van't Hoff, W. (1969). Lancet, 2, 1399.

Bercovici, B., and Ehrenfield, E. N. (1963). Fournal of Obstetrics and Gynaecology of the British Empire, 70, 295.

Bewley, T. A., and Li, C. H. (1970). Science, 168, 1361.

Canfield, C. J., and Bates, R. W. (1965). New England fournal of Medicine,

Dowling, J. J., Richards, J. B., Freinkel, N., and Ingbar, S. H. (1961). Archives of Internal Medicine, 107, 885 .

Forsyth, I. A. (1969). Fournal of Endocrinology, 46, 4.

Forsyth, I. A., Besser, G. M., Edwards, C. R. W., Francis, L., and Myres, R. P. (1971). British Medical fournal, 3, 225.

Frantz, A. G., and Kleinberg, D. L. (1970). Science, 170, 745

Friesen, H., Guyda, H., and Hardy, J. (1970). Journal of Clinical Endocrinology, 31, 611 .

Futterweit, W., and Goodsell, C. H. (1970). Mount Sinai fournal of Medicine,

37, 584. W. H., Saldanha, V. F., Bird, R., and Gardiner, R. (1970).
Havard, C. W. British Medical fournal, $1,337$.

Hennes, A., Waichenberg, B. L., and Ulhoa Cintra, A. B. (1960). Portugal

Médico, 44, 693.
Kinch, R. A. H., Plunkett, E. R., and Derlin, M. C. (1969). American fournal of Obstetrics and Gynecology, 105, 766.

Pasteels, J. L. (1969). In Lactogenesis, ed., M. Reynolds, and S. J. Folley, p. 207. Philadelphia, University of Pennsylvania Press.

Peake, G. T., McKeil, D. W., Jarett, J., and Daughaday, W. H. (1969). Journal of Clinical Endocrinology, 29, 1383.

Ross, R., and Nusynowitz, M. L. (1968). Fournal of Clinical Endocrinology, 28, 591 .

Shearman, R. P., and Turtle, J. R. (1970). American fournal of Obstetrics and Gynecology, 106, 818.

\section{PRELIMINARY COMMUNICATIONS}

\section{Creatine Phosphokinase in Facio- scapulohumeral Muscular Dystrophy}

\author{
B. P. HUGHES
}

British Medical fournal, 1971, 3, 464-465

\section{Summary}

Study of the serum creatine kinase levels in young patients with facioscapulohumeral muscular dystrophy suggests that enzyme assay may be valuable as a screening procedure for assessing the status of relatives of an affected individual who have no previous clinical history, and that consequently it may be of use in genetic counselling.

\section{Introduction}

It is recognized that serum enzyme estimations are valuable in the early diagnosis of Duchenne muscular dystrophy of the sex-linked recessive type (Chung, Morton, and Peter, 1960; Pearce, Pennington, and Walton, 1964; Hughes, 1965). Enzyme activities, particularly aldolase (Chung et al., 1960; Thomson, Leyburn, and Walton, 1960) and creatine phosphokinase (CPK) (Pearce et al., 1964; Hughes, 1965), are grossly raised at an early stage but decline with age, though in the case of serum CPK seldom reach normal values.

Though Thomson et al. (1960) reported that in facioscapulohumeral dystrophy as in Duchenne dystrophy the highest serum aldolase levels were found in young patients, in over half of their series of 15 cases the enzyme activities were below the upper limit of normal, and raised values were found only in patients in whom the "duration" of the disease did not exceed 10-15 years. Consequently a study of serum CPK levels in facioscapulohumeral dystrophy in relation to age seemed worth while in order to assess their value as an aid to early detection of the condition because they are raised to a greater extent than those of aldolase (Heyck and Laudahn, 1967). The usefulness of a biochemical test as an adjunct to clinical examination is apparent when the great variation in clinical expression of this disorder, even within the same family, is considered. As Walton and Gardner-Medwin (1969) pointed out, some individuals may be unaware that they are suffering from the condition and the existence of the characteristic facial weakness may occasionally be difficult to prove.

This communication presents results of serum CPK assays on a number of patients with facioscapulohumeral dystrophy

which suggest that this possibility merits further study.

Muscular Dystrophy Research

B. P. HUGHES, PH.D., Honorary Senior Lecturer and Research Fellow 